\author{
@() (1) \\ Jurnal Pendidikan Dasar Indonesia is licensed under \\ A Creative Commons Attribution-Non Commercial 4.0 International License
}

\title{
GENDER DIFFERENCES (PURUSA PRADANA) AND METACOGNITIVE SKILLS IN BALI
}

\author{
Putu Eka Suarmika ${ }^{1)}$, Erdi Guna Utama ${ }^{2)}$ \\ ${ }^{1)}$ PGSD Universitas Abdurachman Saleh Situbondo, Jawa Timur \\ E-mail: eka_suarmika@yahoo.com \\ 2) PGSD STKIP Singkawang, Kalimantan Barat \\ E-mail:Erdi.guna.utama@gmail.com
}

\begin{abstract}
Balinese culture places women as subordinate because there is a misconception of the concept of purusa and pradana. Indeed purusa and pradana exist in every man including also in women. Purusa is the soul and pradana is the body.Basically, gender issues are not just about the problems of male and female relationships, but also with the issue of education. The purpose of this study was to determine the effect of gender differences (purusa and pradana) on the metacognitive skills of grade 5 primary school students. The survey design used was cross sectional survey design, the researchers collected data at a single point of time. The data collected were metacognitive skill data of grade 5 primary school students. Based on the results of empirical analysis, there is no significant difference between men and women on metacognitive skills with sig 0.672>0.05. Metacognitive, especially skill is not something to be gained but needs to be trained in learning both in school, family and society. This means that to form students who have high metacognitive skills need cooperation between the school as a formal executive education with school committees (parents of students) by utilizing various sources that exist in the student environment are located
\end{abstract}

Keywords: gender, purusa and pradana, metacognitive skills

\section{INTRODUCTION}

In the Balinese custom which adheres to the patriarchy the difference in the treatment of women is very subtle. Balinese culture places women as subordinate because there is a misconception of the concept of purusa and pradana. Indeed purusa and pradana exist in every man including also in women. Purusa is the soul and pradana is the body. However, in the realization of purusa is still interpreted as the soul, only pradana is defined as objects. If the soul never dies alias will survive while the thing is a dead item so it does not need to be treated humanely. This false belief continues in the daily lives of Hindu women in Bali. The presence of men and women is not to be contradicted, but is complementary to the realization of dampati (inextricably) in life

The issue of gender is not really a new thing, because since man was born in this world has been distinguished into two different sexes, namely men and women. At the same time, there has been a socio-cultural construction about the role of each of these creatures and the air. Basically, gender issues are not just about the problems of male and female relationships, but also with the issue of education

One of the important components in the implementation of learning is the process of thinking. This thinking process serves as a basis for what learners do in the investigation and delivery of arguments when composing new knowledge. The problems that always occur in the learning process is the process of thinking that is not optimal when learners learn and the inability to utilize the knowledge that has been obtained, so that the desired learning objectives are not achieved. The problem is related to the metacognitive skills of learners

Metacognition leads to the ability of high order thinking involving active control of a particular cognitive 
process in learning. Some activities like planning how to complete a given assignment, to monitor comprehension, and to evaluate cognitive development, belong to metacognitive activities in daily life. Metacognitive skills helped students make a plan, follow a certain progress, and monitor their own learning process (Imel, 2002). Bahri and Corebima (2015) Metacognitive skill is considered playing an important role in many types of cognitive activity, including comprehension. The activation of metacognitive skill might create a self-regulated learner and might affect to the improvement of learning outcome. Metacognitive skill is one of the aspects of knowledge dimension and an interesting skill to be studied further

Bali is an area that has strong cultural roots, customs and religions as well as a major tourist destination of the world. The Balinese society holds a strong cultural tradition in the life of society. Purusa and pradana concept in Hinduism and indigenous peoples in Bali aims to achieve balance in life which is Santhi/peaceful in spiritual and physical happiness. The terms purusa and pradana in Balinese dictionary are termed as follows: "purusa means the families of the men and Pradana means the families of the women". Purusa and pradana in Bali customary inheritance law is always a consideration in determining who is entitled as an heir and that as the successor to the offspring of the male Agung, et al (2016)

This study Ajisukmo and Saputri (2017) shows that metacognitive knowledge and metacognitive regulations are two important aspects of learning. Therefore, training on how to use both aspects is regarded crucial, thus, research on the effectiveness of the training can be planned for the future. Bahri and Corebima (2015) based on the findings and the discussions, it can be concluded that the contributions of learning motivation and metacognitive skill simultaneously are very high in PBL-RQA, PBL, RQA, and conventional learning strategies on students' cognitive learning outcome. Besides, it is identified that the contribution of metacognitive skill on students' cognitive learning outcome was higher than he contribution of learning motivation.

Veenman (2014) research faund a gender-age interaction in metacognitive skills. Female participants were expected to show a pause or decline in growth and a subsequent resumption of growth one year ahead of male participants. a significant gender by age interaction, much in line with the expectations. Females started out low in class 2 , recovered in class 3 , and finally peaked in class 4 . Males, on the other hand, started positive in class 2 , declined in class 3 , and recovered in class 4 .

\section{MATERIALS AND MeTHODS}

The purpose of this study was to determine the effect of gender differences (purusa and pradana) on the metacognitive skills of grade 5 primary school students.

The sample in this study were 126 students with 62 male students and 64 female students. data collection techniques with questionnaires, consisting of 30 questions with metacognitive skills indicator namely: planning, monitoring and evaluation. The questionnaire used refers to the Likert pattern. Scoring of respondents' answers is as follows: Very Often (4), Often (3) Sometimes (2), and Never (1).

Survey research is a procedure in quantitative research in which the researcher administers the survey on a sample or in the entire population of people to describe attitudes, opinions, behaviors, or special characteristics of the population. The survey design used was cross sectional survey design, the researchers collected data at a single point of time. The data collected were metacognitive skill data of grade 5 primary school students. To determine the effect of nonparametric stattistik analysis using Mann Whitney test with SPSS 16 for Windows

\section{RESULTS}

Based on data analysis of metacognitive skills of elementary school students get results like the table below

Table 1. Metacognitive skills of students

\begin{tabular}{c|c|c|c|c|c}
\hline Gender & $\mathrm{N}$ & $\begin{array}{c}\text { Mini } \\
\text { mum }\end{array}$ & $\begin{array}{c}\text { Maxi } \\
\text { mum }\end{array}$ & $\begin{array}{c}\text { Me } \\
\text { an }\end{array}$ & $\begin{array}{c}\text { Std. } \\
\text { Deviatio } \\
\mathrm{n}\end{array}$ \\
\hline Male & 62 & 68.00 & 102.00 & $\begin{array}{c}90 . \\
80\end{array}$ & $\begin{array}{c}7.70381 \\
\text { female }\end{array}$ \\
& 64 & 40.00 & 108.00 & $\begin{array}{c}91 . \\
25\end{array}$ & 9.66256 \\
\hline
\end{tabular}

Table 1 shows that the average metacognitive skill for male students is 90.80, min values 68 and $\max 102$, and standard deviation of 9.66 . While female students score an average of 91.25 , min 40 and max value 108 . By looking at differences from average, both male and female have high metacognitive skill categories (aware of their own thought processes and can differentiate the stages of input, elaboration and the output of his own mind, sometimes using models to organize his own thinking and learning)

To test the effect of gender differences on metacognitive skills a non-parametric analysis was used with Mann-Whitney test. The results of the analysis are presented in Table 2

Tabel 2. Test Statistics ${ }^{\mathrm{a}}$

\begin{tabular}{l|l}
\hline & Metaskill \\
\hline Mann-Whitney U & $1.898 \mathrm{E} 3$ \\
Wilcoxon W & $3.850 \mathrm{E} 3$ \\
Z & -.423 \\
Asymp. Sig. (2-tailed) & .672 \\
\hline
\end{tabular}

a. Grouping Variable: gender

Based on table 2 we get $\mathrm{U}$ value equal to $1.898 \mathrm{E} 3$, Wilcoxon $\mathrm{W}$ equal to $3,850 \mathrm{E} 3$ with $\mathrm{Z}$ equal to $-0,423$ and sig 0,672 . This means that there is no significant difference 
between gender to students' metacognitive skills (sig .672> $0.005)$. If there is difference of sig value $<0,05$.

\section{DISCUSSION}

The results of the analysis show that there is no significant difference between male and female students of metacognitive skills. This is in line with findings from Misu and Masi (2016) there is no significant difference in metacognition awareness between male students and female students, the results of this study indicate that the awareness of metacognition of mathematics education students both men and women alike are at the stage of problem solving process, and feel confused in determining how to get answers. Similarly, the results of Jaleel and Premachandran (2016) there is no significant difference in the metacognitive awareness of secondary school students based on their gender.

Women in Hindu theology are not small pieces of male personification, but are an equal, equally powerful, equally decisive part in the whole embodiment of life. The theological term is "Ardhanareswari". Ardha means half, same cleavage. Nara means (man) man. Iswari means (human) woman. Without the element of femininity, an incarnation will not occur in full and in Hinduism this element gets the same portion as the right and left hemispheres in humans. As the upper hemisphere is the sky with the lower hemisphere of the earth that both have a duty, a balanced power to achieve harmony in nature and human life in this nature.

In Siwatattwa known the concept of Ardhanareswari is the symbol of God in manifestation as half purusa and pradana. The position and role of Purusa is symbolized by Shiva while Pradana is symbolized by Dewi Uma. In the process of creation, Shiva plays a masculine function while Dewi Uma plays a feminine function. Nothing will be created if the forces of purusa and pradana do not coalesce. The unification of the two elements is believed to still provide bayu (energy) for the creation of various creatures and plants that exist.

From the concept of Ardhanariswari it suggests that women have equal position with men. Women in Hindu theology are not without meaning. In fact, he is considered very meaningful and noble as the foundation of the happiness of the household. Inside Yayurveda (XIV.21) it is explained that women are the pioneers, the one who always advocates the importance of the rules and he himself implements them.

The man of God's creation in function as a purusa symbolized by the phallus. Because women also, the various forms of offerings will be done, because women also calm and tranquility will be realized. Things that can be interpreted from the above description is the woman is a creature of God who has the complexity of its own roles and glory (religious, aesthetic, economic, and social). As a religious being, he becomes perfect in the sight of God, as well as a detailed regulator of aspects of housekeeping, as well as an honest cashier for their family.
Metacognitive skills for students in Bali can not be separated from the concept of tri hita karana (Parhayangan, Pawongan and Palemahan). Human relationship with god (Parhayangan) can be done with Bhakti. The meaning of this Bhakti word is to believe in everything that exists in this world is the grace of God, our way to a sense of gratitude and gratitude is to do a yadnya (sacrifice) by knowing yadnya nature before, on the other side can be done by way of his command and avoid all the restrictions. Human relationships with fellow human beings (Pawongan) can be done with a form of tresna, the word tresna comes from the word love and affection, so therefore a tolerance and mutual respect between people is necessary to make a civilized man. Human relationship with the natural environment (Palemahan) can be done with the form of sih asih, sih asih is a word that berintisari with the meaning of the word remember, neat and have a sense of pity of a thing. Therefore it must and must be legal to maintain the ecosystem of the surrounding environment, because in essence what if the nature is not maintained again the edges we will lose because the enactment of natural law is not indiscriminate and can not be engineered.

Oguz and Ataseven (2016) In teacher education curriculums, designing activities that can develop students' metacognitive skills can be said to help them learn to learn and to increase their motivation. In curriculum, teachers should allocate time for learning strategies teaching, reflective thinking activities and they should also encourage students to read books. Teaching learning strategies can be said to develop students' metacognitive skills. It could also be investigated how some variable activities composed of different techniques affect students' metacognitive skills and motivation. Furthermore, students metacognitive skills and motivation can be investigated with different variables such as self-regulation, self-efficacy, problem-solving skills, reflective thinking.

\section{CONCLUSION}

Based on the results of empirical analysis, there is no significant difference between men and women on metacognitive skills with sig 0.672> 0.05 . That is, the metacognitive skills of the students are influenced by several fator: teachers, curriculum, local culture, motivation, models and learning approaches, learning styles, and psychological factors. Metacognitive, especially skill is not something to be gained but needs to be trained in learning both in school, family and society. This means that to form students who have high metacognitive skills need cooperation between the school as a formal executive education with school committees (parents of students) by utilizing various sources that exist in the student environment are located.

\section{ACKNOWLEDGEMENTS}

A thank you to all students in sub district gerokgak buleleng bali indonesia which has filled the questionnaires and 
teachers who accompany the class in the filling questionnaire

\section{Conflict of interests}

Authors declare no conflict of interest

\section{REFERENCES}

Ajisuksmo, C. R. P., \& Saputri, G. R. (2017). The Influence of Attitudes towards Mathematics, and Metacognitive Awareness on Mathematics Achievements. Creative Education, 8, 486-497. https://doi.org/10.4236/ce.2017.83037

Agung, A. A. I., Sudarsono., Nurjaya, I, N., \& Astiti, T, I, P. (2016). The Interpretation of Purusa and Pradana in Judicial Resolution Regarding Disputes on Heirloom in Bali. http://www.iiste.org/Journals/index.php/JLPG/article/view/296 51. 11-21

Bahri, A. \& Corebima, A, D. (2015). The Contribution Of Learning Motivation And Metacognitve Skill On Cognitve Learning Outcome Of Student Within Different Learning Strategies. http://oaji.net/articles/2016/987-1479498242.pdf. 487-500

Imel, S. (2002). Metacognitive skills for adult learning. Clearinghouse on Adult, Career and Vocational Education. Trends and Issues Alert No. 39. http://eric.ed.gov/?id=ED469264.

Jaleel, S \& Premachandran, P. (2016). A Study on the Metacognitive Awareness of Secondary School Students. www.hrpub.org/journals/article info.php?aid=3264. 165-172

Misu, L \& Masi, L. (2016). Comparison of Metacognition Awareness of Male and Female Students Based on Mathematics Ability in Department of Mathematics Education of Halu Oleo University. www.ijern.com/journal/2017/June-2017/04.pdf. 43-50

Oguz, A., \& Ataseven, N. (2016). The Relationship Between Metacognitive Skills and Motivation of University Students. Educational Process: International Journal, 5(1). http://dx.doi.org/10.12973/edupij.2016.51.4. 54-64.

Veenman, M, V. J. (2014). Assessing Developmental Differences inMetacognitive Skills With Computer Logfiles: Gender by Age Interactions. https://www.researchgate.net/.../287242207 